Jurnal Teknik Hidro

Vol. 11 No. 1, Februari 2018

\title{
PENGARUH KEDALAMAN PEMECAH GELOMBANG TERAPUNG PIPA ANYAMAN ECENG GONDOK TERHADAP TINGGI GELOMBANG REFLEKSI DAN TRANSMISI
}

\author{
Nenny T. Karim ${ }^{1}$ dan Andi Makbul syamsuri ${ }^{2}$ \\ 1) Universitas Muhammadiyah Makassar, Indonesia \\ Email : nennykarim@yahoo.co.id \\ ${ }^{2)}$ Universitas Muhammadiyah Makassar, Indonesia \\ Email : syamsuriandimakbul@yahoo.co.id
}

\begin{abstract}
ABSTRAK
Penelitian kali ini bertujuan untuk mengetahui pengaruh kedalaman dan pengaruh periode pada floating breakwater dengan melakukan permodelan dalam skala laboratorium dengan menggunakan bahan eceng gondok kering yang dirakit. Dalam penelitian ini yang dihitung adalah kedalaman refleksi dan kedalaman transmisi gelombang dari model fisik floating breakwater berbahan dasar eceng gondok, yang merupakan perbandingan antara tinggi gelombang datang $(\mathrm{Hi})$ dengan tinggi gelombang yang direfleksikan $(\mathrm{Hr})$ dan tinggi gelombang datang $(\mathrm{Hi})$ dengan tinggi gelombang yang ditransmisikan (Ht), sehingga akan diketahui efektifitas dari floating breakwater dalam meredam gelombang. Model floating breakwater berbahan dasar eceng gondok di uji di wave flume menggunakan gelombang irreguler dengan tinggi gelombang 1 sampai $3 \mathrm{~cm}$ dan periode 1,7 detik, 1,9 detik, 2,1 detik dan dengan 3 variasi kedalaman tenggelam model yakni $15 \mathrm{~cm}, 18 \mathrm{~cm}$ dan $21 \mathrm{~cm}$. Hasil penelitian menunjukkan padakedalaman mtenggelam model $15 \mathrm{~cm} \mathrm{Hr}$ berkisar 0,1-0,5 CM dan Ht berkisar $2-2,8 \mathrm{~cm}$. Pada kedalaman $18 \mathrm{~cm} \mathrm{Hr}$ berkisar 0,2-0,45 cm dan $\mathrm{Ht}$ berkisar 1,8-2,2 cm. Pada kadalaman $21 \mathrm{~cm} \mathrm{Hr}$ berkisar 0,15-0,45 cm dan Ht berkisar 1,6-2,15 cm. Dari hasil pengujian menunjukkan kedalaman tenggelam model $21 \mathrm{~cm}$ lebih efektip mengurangi tinggi gelombang Refleksi dan tinggi gelombang Transmisi.
\end{abstract}

Kata kunci : Floating Breakwater, Gelombang Refleksi, Gelombang Transmisi.

\begin{abstract}
ABSTRAC
The Purpose study aims to determine the ability of a floating breakwater to do modeling in laboratory scale with the use of dried water hyacinth assembled beam-shaped.. in this study were calculated is the reflection coefficient and the coefficient of the transmission waves of a physical model of floating breakwater made from water hyacinth, which is the ratio between the height of the incoming wave $(\mathrm{Hi})$ to the height of the waves are reflected $(\mathrm{Hr})$ and wave height coming $(\mathrm{Hi})$ with wave heights transmitted $(\mathrm{Ht})$, so they will know the effectiveness of the floating breakwater made of water hyacinth in reducing gelombang.floating breakwater models made from water hyacinth tested in wave flume using irregular waves with wave heights of 1 to $3 \mathrm{~cm}$ and a period of 1.7 seconds, 1.9 seconds, 2.1 seconds and premises 3 variations of singking depth of $15 \mathrm{~cm} \mathrm{Hrmodel}$ ranges from 0,1-0,5 cm andranges 1,8-2,2 cm.At depth of $18 \mathrm{~cm} \mathrm{Hr}$ ranges $0,2-0,45$ and $\mathrm{Ht}$ ranges 1,8 - 2,2 At depth of $21 \mathrm{~cm} \mathrm{Hr}$ ranges $0,15-0,45$ and $\mathrm{Ht}$ ranges 1,62,15. Of the test results show the depth of sink $21 \mathrm{~cm}$ model more effectively reduce the reflection wave height and transmission wave height.
\end{abstract}

Keyword : Floating Breakwater, coefficient wave, ransmission wave. 


\section{PENDAHULUAN}

Pemerintah telah berupaya untuk menanggulangi pantai dengan cara penghijauan pantai, yaitu menanam pohon bakau. Bakau dapat tumbuh dengan baik jika telah mencapai tiga bulan. Permasalahan yang muncul adalah bakau yang baru ditanam tidak bisa tumbuh dengan baik, sebab sebelum tumbuh sudah dihempas oleh gelombang. Oleh sebab itu perlu dibuat suatu pelindung untuk melindungi bakau yang baru ditanam agar tidak terbawah oleh gelombang. Oleh karena sifatnya hanya untuk melindungi anak bakau yang baru ditanam, maka seharusnya bahannya mudah diperoleh dan harganya terjangkau. Dengan dasar ini kami berinisiatif untuk meneliti pemecah gelombang terapung (floating breakwater) berbahan dasar eceng gondok.

Tujuan dari penelitian ini untuk mengetahui potensi redaman yang dihasilkan floatingbreakwater berbahan dasar eceng gondok.

\section{Refleksi Gelombang}

Besar kemampuan suatu bangunan pemecah gelombang untuk memantulkan gelombang dapat diketahui melalui koefisien refleksi. Koefisien refleksi adalah perbandingan antara tinggi gelombang refleksi $(\mathrm{Hr})$ dan tinggi gelombang datang (Hi).

Sehingga diperoleh persamaan :

$$
\begin{gathered}
H_{i}=a_{\max }+a_{\min } \\
H_{r}=a_{\max }-a_{\min } \\
H_{i}-H_{r}=2 a_{\max } d_{a n H_{i}}-H_{r} \\
=2 a_{\min }
\end{gathered}
$$

Tinggi gelombang datang adalah:

$$
\begin{aligned}
H_{i} & =\frac{2 a_{\max }+2 a_{\min }}{2} \\
& =\frac{H_{\max }+H_{\min }}{2} \ldots \ldots \ldots \ldots
\end{aligned}
$$

Tinggi gelombang refleksi adalah:

$$
\begin{aligned}
H_{r} & =\frac{2 a_{\max }-2 a_{\min }}{2} \\
& =\frac{H_{\max }-H_{\min }}{2} \ldots \ldots \ldots \ldots
\end{aligned}
$$

Tinggi gelombang datang $\left(\mathrm{H}_{\mathrm{i}}\right)$ dan refleksi $\left(\mathrm{H}_{\mathrm{r}}\right)$ pada model ditentukanberdasarkan tinggi gelombang maksimum $\left(\mathrm{H}_{\max }\right)$ dan tinggi gelombang minimum $\left(\mathrm{H}_{\min }\right)$ darihasil pengukuran tinggi gelombang dari beberapa titik.

\section{Transmisi Gelombang}

Transmisi gelombang merupakan penerusan gelombang melalui suatu bangunan yang parameternya dinyatakan sebagai perbandingan antara tinggi gelombang yang 
ditranmisikan ht terhadap tinggi gelombang hi.

$$
\begin{aligned}
H_{t} & =\frac{2 a_{\max }+2 a_{\min }}{2} \\
& =\frac{H_{\max }+H_{\min }}{2} \ldots \ldots \ldots \ldots
\end{aligned}
$$

\section{Eceng Gondok}

Eceng gondok (Eichhornia Crassipes) adalah salah satu jenis tumbuhan yang mengapung di atas permukaan air. merusak lingkungan perairan.

Namun, tingkat pemanfaatan eceng gondok tidak sebanding dengan tingkat pertumbuhannya yang mencapai $1,9 \%$ per hari. Serta tingkat perkembangbiakannya, dimana 10 tanaman ini dapat menjadi 600.000 tanaman dalam waktu 8 bulan (Van Stenis dalam Sri Kusumawati 1995). Eceng gondok mengandung kadar air sebesar $90 \%$ dengan tingkat reduksi berat dari $10 \mathrm{~kg}$ basah menjadi $1 \mathrm{~kg}$ kering. Dalam keadaan kering eceng gondok mengandung protein kasar $13,03 \%$, serat basah 20,6 \%, lemak $1,1 \%$, abu $23,8 \%$ dan sisanya berupa vortex yang mengandung polisakarida dan mineral- mineral (Suwardi dan Utomo 1975). Eceng gondok berpotensi dikembangkan dalam bidang komposit berbasisi serat alam, dengan kandungan serat yang ulet dan tinggi sehingga tahan terhadap air. Dengan gagasan ini tumbuhan eceng gondok memiliki manfaat yang lebih banyak lagi jadi pertumbuhan dan pemanfaatannya bisa seimbang sehingga perairan bisa bersih dari eceng gondok dan perairan tersebut dapat berfungsi dengan baik sebagaimana mestinya. Pelindung pantai bisa diolah dan diproduksi sendiri oleh masyrakat khususnya masyarakat nelayan. Serta bisa mengurangi abrasi di daerah pesisir.

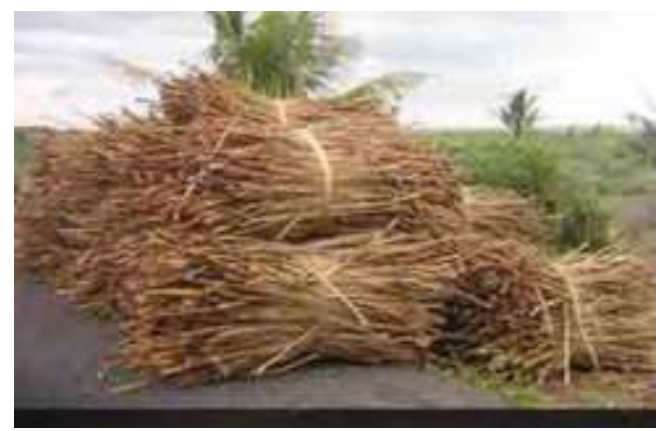

Gambar 1. Eceng gondok kering

\section{METODE PENELITIAN}

Sebelum penelitian laboratorium hal yang sangat penting adalah pembuatan model. Eceng gondok harus benar benar kering. Setelah itu dirakit berbentuk balok dengan ukuran panjang $45 \mathrm{~cm}$ lebar $27 \mathrm{~cm}$ dantinggi $21 \mathrm{~cm}$.

\section{Karakteristik Gelombang}


Karasteristik gelombang yang dihasilkan oleh wave generator terdiri dari tiga variasi periode dan satu tinggi gelombang. Periode gelombang dikontrol oleh putaran pulley. Tinggi gelombang dikontrol oleh posisi stroke yang mengatur gerakan flap. Sedangkan kedalaman air pada flume adalah $25 \mathrm{~cm}$. Data karasteristik diperoleh sebelum diletakkan model peredam gelombang.

Tabel 1. Karasteristik gelombang

\begin{tabular}{c|cc|c}
\hline $\begin{array}{c}\text { Kedala } \\
\text { man }\end{array}$ & \multicolumn{2}{|c|}{$\begin{array}{c}\text { Periode } \\
\text { Gelombang }\end{array}$} & $\begin{array}{c}\text { Tinggi } \\
\text { Gelomb } \\
\text { ang }\end{array}$ \\
\hline $\mathrm{cm}$ & \multicolumn{2}{|c|}{ detik } & $\mathrm{cm}$ \\
\hline 25 & Pulley 1 & 1,7 & 3 \\
\hline 25 & Pulley 2 & 1,9 & 3 \\
\hline 25 & Pulley 3 & 2,1 & 3 \\
\hline
\end{tabular}

Pelaksanaan Simulasi Model

Pelaksanaan simulasi model dilakukan dengan mengukur tinggi gelombang pada 9 titik di depan dan di belakang model. Pengukuran tinggi gelombang yang dibangkitkan pada kondisi stabil, yaitu beberapa saat setelah gelombang dibangkitkan. Adapun pelaksanaannya sebagai berikut:

a) Pertama model diletakkan dijarak $9 \mathrm{~m}$ dari pembangkit gelombang yang dimana ukuran flume yang digunakan $15 \mathrm{~m}$. b) Percobaan pembangkit gelombang dilakukan untuk melakukan kalibrasi alat pencatatan tinggi gelombang.

c) Setelah semua komponen siap, pelaksanaan pengambilan dimulai dengan membangkitkan gelombang dengan menekan tombol star pada kontrol pembangkit gelombang.

d) Tinggi gelombang maksimal dan minimum di depan dan dibelakang model diukur dan dicatat pada masing-masing titik.

e) Prosedur dipoin c dan d dilakukan berulang-ulang dengan variasi jarak model yang berbeda dalam variasi parameter periode gelombang (T) dan tinggi gelombang datang.

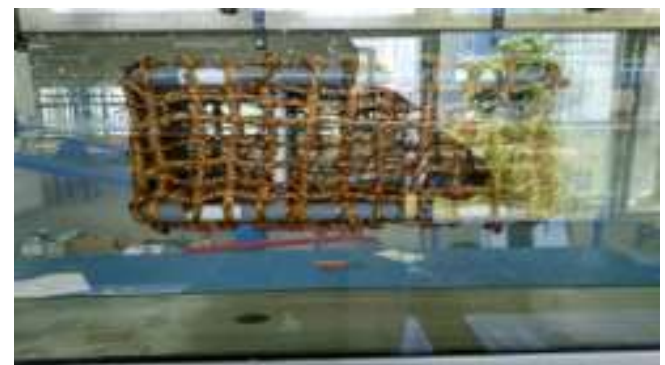

Gambar 2. Perletakan model dalam wave flume 


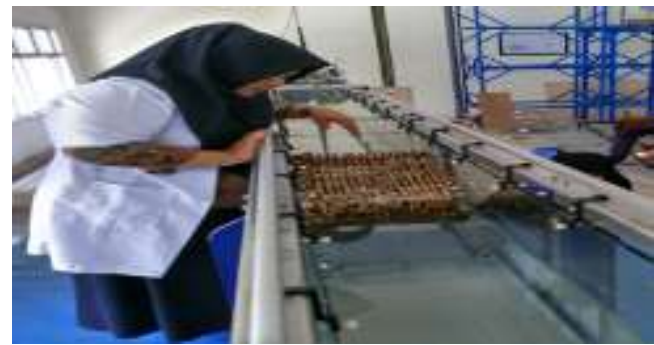

Gambar 3. Perletakan model dalam flume

\section{Prosedur Penelitian}

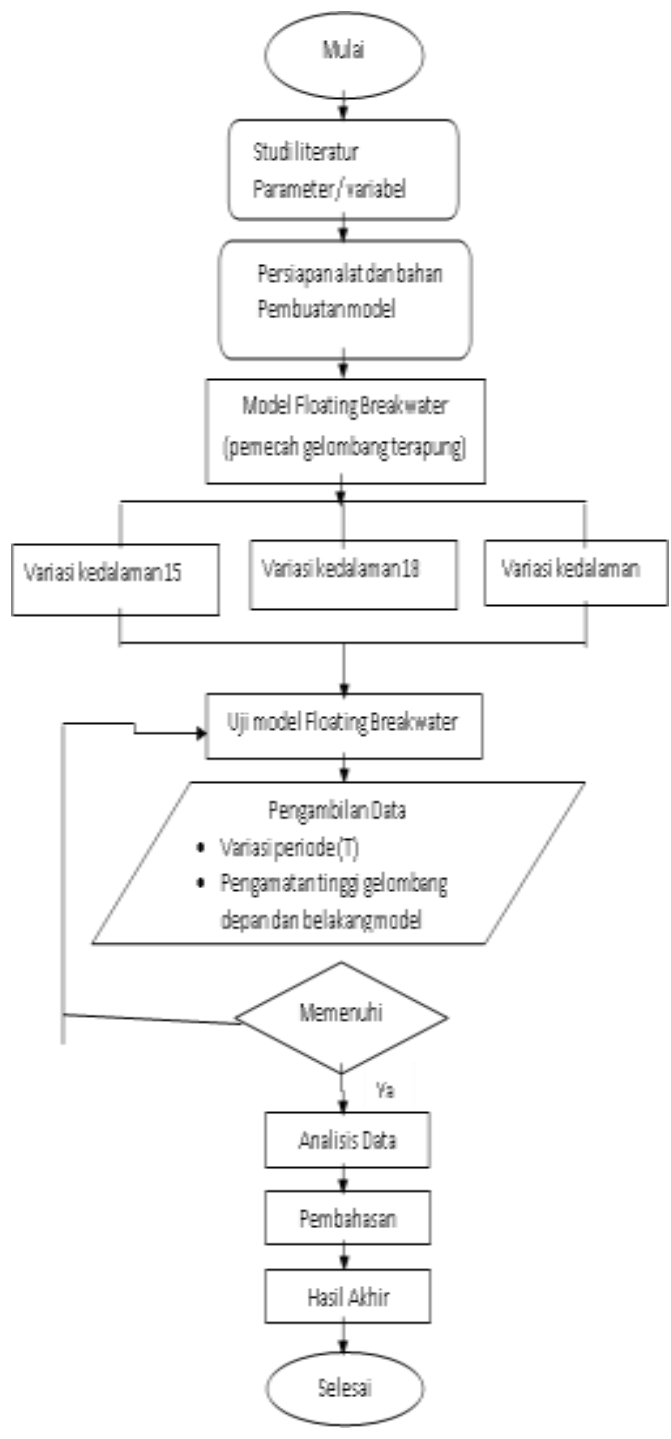

Gambar 4. Flowchart prosedur penelitian
HASIL DAN PEMBAHASAN
Hubungan Parameter Tinggi

Gelombang Refleksi (Hr) dengan

\section{Kedalaman Tenggelam Model}

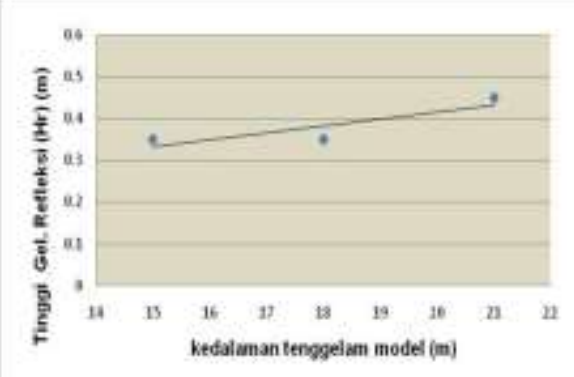

Gambar 5. Hubungan antara tinggi gelombang refleksi (Hr) dengan kedalaman tenggelam model

Dari hasil pengamatan di atas, dapat dilihat dari grafik bahwa tinggi gelombang refleksi (Hr) berbanding lurus dengan kedalaman tenggelam model. Semakin dalam tenggelamnya model semakin besar nilai tinggi gelombang refleksi (Hr) yang dihasilkan.

\section{Hubungan Parameter Tinggi Gelombang Transmisi (Ht) dengan Kedalaman Tenggelam Mode}

Berdasarkan hasil pengamatan data pada sub bab sebelumnya diperoleh Tinggi gelombang transmisi $(\mathrm{Ht})$ dan kedalaman tenggelam model. Jika mengambil tinggi gelombang transmisi (Ht) sebagai variabel sumbu 
$\mathrm{Y}$ dan kedalaman tenggelam model sebagai sumbu $\mathrm{X}$ maka akan didapatkan grafik seperti gambar berikut.

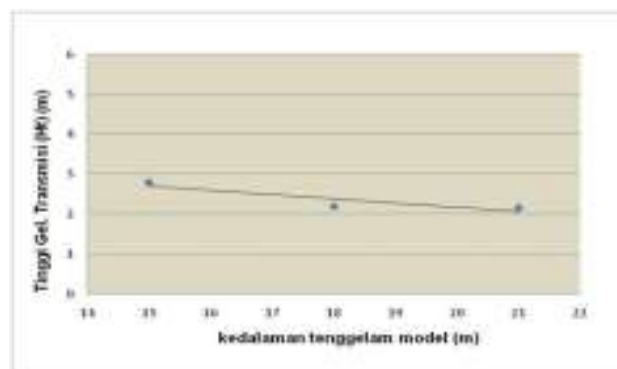

Gambar 6. Hubungan antara tinggi gelombang transmisi (Ht) dengan kedalaman tenggelaman model

Dari hasil pengamatan di atas, dapat dilihat dari grafik bahwa tinggi gelombangtransmisiberbanding terbalik dengan kedalaman tenggelam model. Semakin dalam tenggelamnya model semakin keciltinggi gelombang transmisi yang dihasilkan.

\section{Hubungan Tinggi Gelombang}

\section{Refleksi (Hr) dengan Variasi}

Kedalaman Tenggelam Model (d1, d2, d3)

Untuk menyajikan hubungan tinggi gelombang $(\mathrm{Hr})$, dengan kedalaman tenggelam model maka diambil $\mathrm{Hr}$ sebagai sumbu $\mathrm{Y}$ dan kedalaman tenggelam model $(\mathrm{d} 1, \mathrm{~d} 2, \mathrm{~d} 3)$ sebagai sumbu $\mathrm{X}$ untuk tiap kedalaman tenggelam model maka akan didapat grafik seperti gambar di bawah ini.

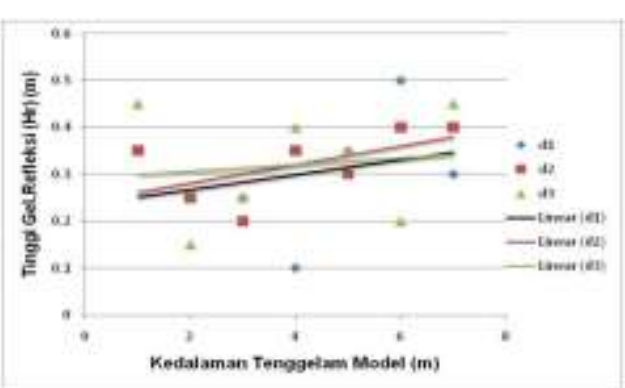

Gambar 7. Hubungan tinggi gelombang refleksi dengan kedalaman tenggelaman model.

Dari hasil pengamatan di atas dapat dilihat dari grafik bahwa tinggi gelombang refleksi berbanding lurus dengan kedalaman tenggelam model. Semakin dalamtenggelamnya model semakinbesar nilai tinggi gelombang refleksi. Hal ini disebabkan karena adanya pengaruh periode di setiap kedalaman tenggelam model.

\section{Hubungan Tinggi Gelombang} Transmisi (Ht) dengan Variasi Kedalaman Tenggelam Model (d1, d2, d3)

Untuk menyajikan hubungan tinggi gelombang (Ht), dengan kedalaman tenggelam model maka diambil $\mathrm{Ht}$ sebagai sumbu $\mathrm{Y}$ dan kedalaman tenggelam model $(\mathrm{d} 1, \mathrm{~d} 2, \mathrm{~d} 3)$ sebagai sumbu $\mathrm{X}$ untuk tiap kedalaman 
tenggelam model maka akan didapat grafik seperti gambar di bawah ini.

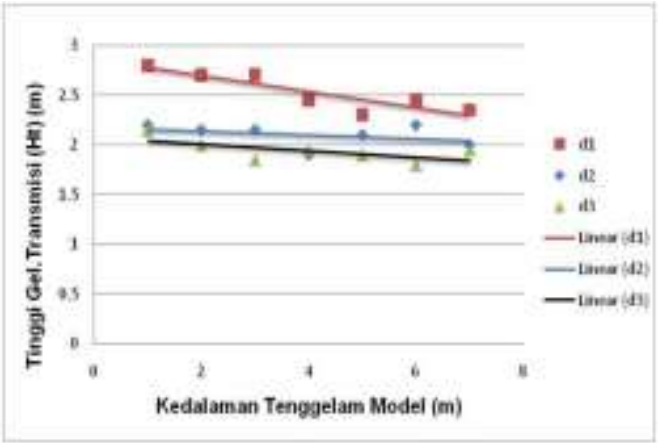

Gambar 8. Hubungan tinggi gelombang transmisi $(\mathrm{Ht})$ dengan kedalaman tenggelam model.

Dari hasil pengamatan di atas dapat dilihat dari grafik bahwa tinggi gelombang transmisi berbanding terbalik dengan kedalaman tenggelam model. Semakin dalam tenggelamnya model semakin kecilnilai tinggi gelombang transmisi yang dihasilkan. Hal ini disebabkan karena adanya pengaruh periode di setiap kedalaman tenggelam model.

\section{Hubungan Periode (T) dengan Tinggi Gelombang Refleksi (Hr)}

Untuk menyajikan hubungan periode (T) dengan tinggi gelombang refleksi $(\mathrm{Hr})$, maka diambil periode $(\mathrm{T})$ sebagai sumbu $\mathrm{X}$ dan tinggi gelombang refleksi (Hr) sebagai sumbu Y untuk tiap kedalaman tenggelam model maka akan didapat grafik seperti gambar.

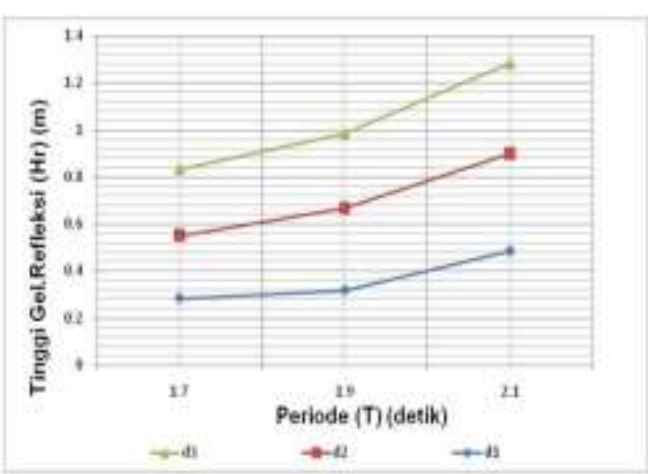

Gambar 9. Hubungan periode gelombang (T) dengan tinggi gelombang gelombang refleksi $(\mathrm{Hr})$ pada kedalaman tenggelaman model.

Pada gambar di atas menunjukkan bahwa semakin lama periode maka semakin meningkat nilai tinggi gelombang refleksi baik kedalaman tenggelam model $15 \mathrm{~cm}, 18 \mathrm{~cm}$ maupun $21 \mathrm{~cm}$.

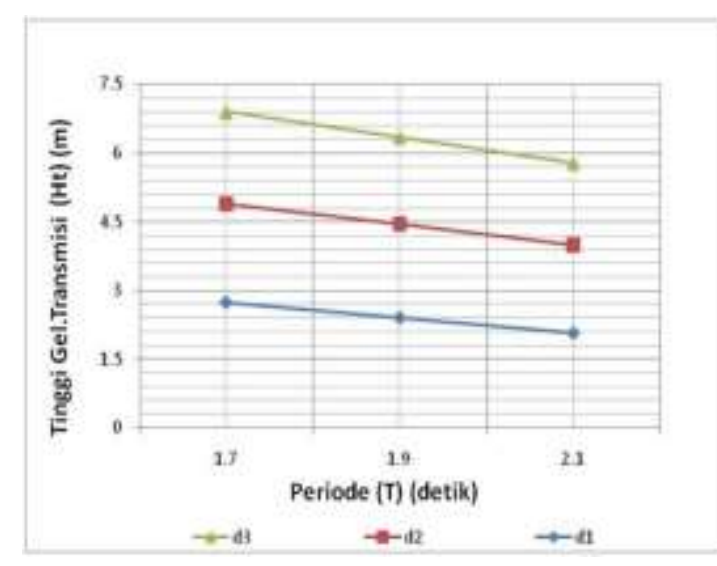

Gambar 10. Hubungan periode gelombang (T) dengan tinggi gelombang gelombang transmisi $(\mathrm{Ht})$ pada kedalaman tenggelaman model.

Untuk menyajikan hubungan periode (T) dengan tinggi gelombang (Ht), 
Jurnal Teknik Hidro

\section{Vol. 11 No. 1, Februari 2018}

maka diambil periode (T) sebagai sumbu $\mathrm{X}$ dan tinggi gelombang transmisi (Ht) sebagai sumbu Y untuk tiap kedalaman tenggelam model maka akan didapat grafik seperti gambar.

Pada gambar di atas menunjukkan bahwa semakin lama periode maka semakin menurun nilai tinggi gelombang transmisi baik kedalaman tenggelam model $15 \mathrm{~cm}, 18 \mathrm{~cm}$ maupun $21 \mathrm{~cm}$.

\section{PENUTUP}

\section{Kesimpulan}

1) Besarnya Tinggi Gelombang Refleksi (Hr) berbanding lurus dengan kedalaman tenggelam model. Semakin dalam tenggelamnya model semakin besar nilai tinggi gelombang refleksi. Sedangkan untuk besarnya Tinggi Gelombang Transmisi (Ht) berbanding terbalik dengan kedalaman tenggelam model. Semakin dalam tenggelamnya model semakin kecil nilai tinggi gelombang transmisi.

2) Semakin lama periode (T) maka semakin meningkat nilai tinggi gelombang refleksi (Hr) dan semakin lama periode (T) maka semakin menurun nilai tinggi gelombang transmisi $(\mathrm{Ht})$

\section{DAFTAR PUSTAKA}

Anas, Muh. Azwar. 2014. Studi Pemecah Gelombang Blok Beton Berpori Susunan Seri. Jurusan Teknik Sipil Fakultas Teknik Unhas.

Anugerah Nontji, 1987, Laut Nusantara , Penerbit Djambatan, Jakarta

D'Angremond $\mathrm{K}$ and Van Roode F.C,2004, Breakwater and Clousure DAMS. Delf University, New York, USA

Fadlullah, Mirza.2016. Studi Refleksi Gelombang pada Breakwater Tipe Dinding Berpori. Jurusan Sipil Fakultas Teknik Unhas.

Hales, 1981.FloatingBreakwater.Delf University. Belanda

Mc Cartney. 1985. Floating Breakwater.Delf University. Belanda

Martius Carl. Eichhornia Crassipes. Brazil

Suntoyo dkk.1996. Gelombang . Mahakarya. Jakarta

Triatmodjo Bambang. 2010. Perencanaan Pelabuhan. Beta Offset. Yogyakarta 
Jurnal Teknik Hidro

Vol. 11 No. 1, Februari 2018

Triatmodjo Bambang. 2011.

Perencanaan Bangunan

Pantai. Beta Offset.

Yogyakarta

Triatmodjo Bambang.1999. Teknik

Pantai. Beta Offset.

Yogyakarta.

Utomo Dkk. 1975. Pemanfaatan

Eceng Gondok. Djambatan.

Jakarta. 